\title{
INTERROGATING THE MEANING OF A RURAL BUSINESS THROUGH A RURAL CAPITALS FRAMEWORK
}

\author{
Dr Gary Bosworth \\ University of Lincoln
}

Roger Turner

Freelance Rural Economies' Consultant

An earlier version of this paper was presented at the $14^{\text {th }}$ Rural Entrepreneurship Conference, Lincoln June 2016

\begin{abstract}
This paper explores the ways in which businesses use and create diverse forms of rural capital, as an attempt to better understand the distinctive characteristics of "rural businesses". We present three cases to explore the features that might lead us to describe them as being distinctively "rural businesses". This adds to the debate about whether location alone is a sufficient parameter for defining rural-ness.

The business cases were each established in rural areas of northern/central England. The cases were selected to fit an existing categorisation of rural businesses based on personal knowledge about the companies. Data was gathered through a combination of interviews and secondary materials. Our findings indicate that the employment of forms of rural capital is a key dimension along with the locations of firms and their markets, in distinguishing "rural businesses" from others.

A clearer understanding of specifically "rural" characteristics of businesses can guide policy towards approaches that deal with rural challenges and support for businesses to harness characteristics and opportunities connected to rural places. We assert that such approaches would be better tailored to local conditions than broad-brush spatial policies. They also aid understanding of the dynamics of change in rural communities driven by local business development.
\end{abstract}

KEY WORDS: Community Capital Framework; Rural Business; Rural Entrepreneurship; Rural Economy 


\section{INTERROGATING THE MEANING OF A RURAL BUSINESS THROUGH A RURAL CAPITALS FRAMEWORK}

\section{Introduction}

Understanding the characteristics of a rural business is increasingly important, in light of the growing diversity and reach of economic activities in rural areas (Korsgaard et al., 2015; Dubois, 2016). Combined forces of consumerism, rapid developments in communications technology and the relative decline in the economic importance of agriculture in rural areas all reinforce Korsgaard et als (2015) recognition of the need to better understand the extent to which businesses are integrated into rural networks, support rural jobs and provide rural services. The outmigration of younger people (Haartsen and Van Vissen, 2012; Haartsen and Venhorst 2010; Stockdale, 2004) and the ageing of rural communities, itself partly driven by pre-retirement migration patterns (Stockdale and McCleod, 2013), add to the pressure to identify new approaches to vitalising rural economies and communities. In this context, we analyse the meaning and roles of rural businesses by applying the conceptual tool of rural capital, seen here as a nuanced version of territorial capital that includes particular rural identities and rural assets (see section 3 ).

Recent publications, such as the CLA report "Standing up for Rural Businesses" (CLA, 2016), highlight the need for a clearer interpretation of what makes a rural business distinctive, in terms of their opportunities, challenges and business models. In any location, start-ups may simply serve to support lifestyle ambitions among their owners with little prospect of contributing to regional employment, innovation or productivity (Huggins et al., 2015). To promote rural development, though, we need to understand businesses and business models that contribute to the economic and social sustainability of rural places.

The academic debate has also shifted towards an acceptance that a "rural business" is not simply any business in a rural location (Bosworth 2012; Korsgaard et al., 2015; Moyes et al., 2015), particularly given the increasing interconnections and interdependencies between urban and rural economies (Lichter and Brown, 2011). For example, some businesses located in urban areas play pivotal roles in rural supply chains and rural service provision while other businesses located in rural areas are embedded in urban networks and have minimal local economic impact. Korsgaard et al. (2015) make the helpful distinction between "rural entrepreneurship" and "entrepreneurship in the rural", where the latter may be less embedded in the rural locality. To interrogate this complexity further, three case studies are used in this paper as a basis for developing and applying a "rural capitals" framework to 
identify how businesses draw value from their rural locations and make contributions to their local economies.

To frame the analysis, we pose the central research question, "How and to what extent do businesses both use and create diverse forms of rural capital?" This allows the discussion to consider the connection between rural businesses, rural capitals and the vitality of rural places and to more clearly define types of rural businesses. This approach also allows the categorisation of rural businesses presented in earlier work (Bosworth, 2012) to be tightened in response to subsequent critique (Moyes et al., 2015). The paper continues with an overview of the debate about what constitutes a "rural business" before offering a theoretical approach to applying a rural capitals framework to better understanding the character of rural businesses. The three cases then illustrate and extend key aspects of the debate before policy recommendations and conclusions are presented that seek to challenge the hegemony of thinking about the rural as innately disadvantaged in economic terms.

\section{Defining a Rural Business}

As the rural economy is no longer just synonymous with agricultural and primary production, research into broader rural business characteristics and dynamics has flourished. As far back as 1990, Wortman (1990) noted that while is easy to assume that everyone knows what rural entrepreneurship means, the community, economic and cultural development objectives and the relationship between urban and rural entrepreneurship each demand systematic investigation. Internationally, a number of academic authors have charted the growth of farm diversification (Seuneke and Bock, 2015; McElwee and Bosworth, 2010), tourism (Dana et al., 2014; Di Domenico and Miller, 2012; Phelan and Sharpley, 2012), home-based businesses (Newbery and Bosworth, 2010) and creative industries in rural areas (Roberts and Townsend, 2016). Such research builds on, and adds to, substantially improved profiling of the characteristics, challenges and contributions of businesses located in rural areas of the UK (Turner, 2014; Atterton, 2016; Scottish Government, 2016; Phillipson el al., 2017; REUK, 2017; CRC, 2007-11; Defra, 2014-17). In particular, the evolving social construction of rural areas alongside increased mobility has created distinctive opportunities for consumer-focused businesses to prosper in rural areas (Slee, 2004). In England, these areas of growth have emerged alongside declining numbers of traditional retail and health services as well as declining rates of employment in agriculture (Rural England, 2017).

Across Europe, the dominant rhetoric has emphasised that rural businesses suffer from their under-developed economic locations (Stathopolou et al., 2004), where the exodus of younger age groups is detrimental to entrepreneurship (North and Smallbone, 2006). 
Lagging infrastructure and technology compound this rural disadvantage (Malecki, 2003; North and Smallbone, 2006; Salemink et al., 2015). To view rural businesses and opportunities for rural entrepreneurship in a more positive light, it is essential to determine "what is a rural business?" and here this question is addressed according to their creation and use of rural capitals. While an area-level perspective is helpful for broader policymaking, a more nuanced understanding of rural businesses can capture the increasing diversity of entrepreneurial activities in rural areas which harness 'rurality' in a variety of ways (Korsgaard et al., 2015). The "intimate link between the spatial context and the entrepreneurial activities" (ibid, p6) helps to sustain many rural enterprises which in turn support local areas through the creation of economic, social and cultural value. However, this depends on the extent to which actors are locally embedded (Hess, 2004; Dubois, 2016).

Therefore, this paper specifically builds upon a previous proposition whereby a "rural business" should satisfy at least two of the three criteria in Figure 1, which results in areas A, $B, C$ and $D$ representing four groups of rural businesses (Bosworth, 2012). The publication of a detailed case study of a crematorium business established in rural Scotland (Moyes et al., 2015), demonstrated the need to rethink the criterion "Sell a rural product" in order to capture rural businesses' interactions with diverse rural capitals.

\section{Figure 1: Categorising rural businesses}

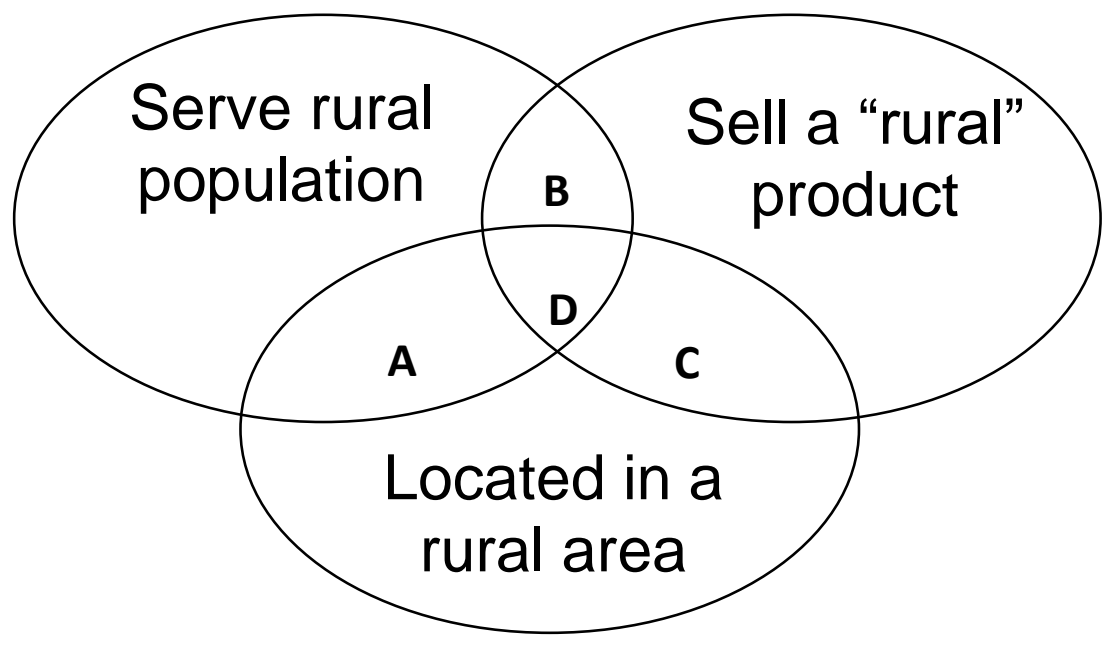

In critiquing Bosworth's earlier paper, Moyes et al. presented their case as a $5^{\text {th }}$ type of rural business: "rural service and rural location" (2015, p. 20). However, unless we can identify what makes the service itself "rural" in character, this appears rather similar to the previously suggested category A, "serving a rural population and based in a rural location" (Bosworth, 2012). Moyes et al.'s new category also claims to include services such as buses and taxis 
but these are not uniquely rural services, rather the rural location changes the nature of their provision. It is the fact that they are serving a rural population that is a defining factor, thus placing them firmly in category A.

Instead, the case of the rural crematorium provides a clear example that the "rural product" dimension in Bosworth's original Figure 1 is inadequately defined. The crematorium business offers a rural service because clients are drawn to a natural setting and see it as being embedded within the local rural milieu. This is the same as customers being drawn to a rural product for reasons of provenance, authenticity or environmental attachment. Therefore, we assert that the crematorium in Moyes et als study should be placed in category $\mathrm{C}$, although given its largely rural customer base one might argue that it could fit into category D. To support this assertion, the remainder of this paper is devoted to tightening the meaning of what it is to "sell a rural product" which we do through the application of a rural capitals framework.

\section{The Rural Capitals Framework as a model for understanding rural business activities}

The concept of "rural capital" was proposed in the US by Castle (1998) who indicated that its "development and conservation... is of fundamental importance to rural people as they exercise their autonomy in addressing common concerns and pursuing their aspirations" (1998; p.622). In this quotation we can see parallels with neo-endogenous development thinking which emerged in Europe at a similar time (Lowe et al., 1998; Ray 2001; 2006; Ward et al., 2005; Terluin, 2003) to advocate the deployment of local assets combined with extra-local networks in the pursuit of development objectives. These might include combinations of tangible (economic, natural and physical) and intangible (social, organisational and cultural) capitals as well as human capital which arguably falls somewhere in between (Svendsen and Sorensen, 2007). Castle suggests that the agglomeration of capitals within the rural economy creates additional value, just as the Community Capital Framework suggests that accrual of different forms of capital within a community can be mutually self-reinforcing (Emery and Flora, 2006; Flora and Flora, 2008).

Rural capital, as an aggregation of forms of capital attached to a given rural territory, could be aligned to the concept of territorial capital, defined as, "the system of territorial assets of economic, cultural, social and environmental nature that ensures the development potential of places" (Perucca, 2014, p. 537). It has been observed that in regions where territorial capital assets play an important role, regional growth performance tends to be stronger (Camagni and Capello, 2009). Capello et al. (2009, p.7) explain that "the success of a 
territorial system does not depend solely on the quantity and quality of the material resources with which it is endowed. It also, and crucially, depends on the richness of cognitive elements, or the way individuals think and behave." The importance of intangible resources, which tend to be more localized and immobile, is emphasised in rural development theory too (Terluin, 2003), leading us to view rural capital as a form of territorial capital. However, we see rural capital as a nuanced version of territorial capital that includes particular rural identities and rural assets drawn from the environment as well as from rural communities. Together these shape the rural character of the intangible networks, norms and behaviours described in the mainstream territorial capital literature.

The rural capitals framework expands upon ideas emerging from community development where it is considered that the growth of all forms of capital (built, natural, social, human, financial, cultural and political) in a community can creating virtuous spirals of development (Emery and Flora, 2006). We therefore propose that the "rural product" in Figure 1 is defined in relation to the rural capitals that are employed in its production, building on an earlier paper exploring the values of local community and landscape assets for rural entrepreneurs (Finke and Bosworth, 2016). In this sense we define rural capital to include the natural, man-made, human and social attribute of rural locations that can generate value for those with access to it (from Castle, 1998), which also provides a wider scope for categorising rural businesses.

The Bristol Accord (OPDM, 2005) set out eight criteria considered to define a sustainable community (see Table 1) and businesses can play key roles in a number of these, not just the goal of creating a thriving, flourishing and diverse local economy (ODPM, 2005).

Businesses have also traditionally played key roles in defining local cultures, providing space for community activities, participating in local governance, supporting transportation and other local service needs, managing and creating the local natural and built environments and providing income and employment for local residents. Svendsen and Sorensen (2007) suggest significant differences in socioeconomic outcomes between communities can be explained by their varying success in capitalising upon local stocks of tangible/intangible capital.

As well as supporting rural community development, these diverse rural assets or capitals can provide added value to sustain and promote rural businesses. Combining the different approaches to understanding and categorising forms of capital in rural communities and their economies, Table 1 sets out four previous presentations of forms of rural capital. The final column provides an aggregated synthesis of the forms of capital that can be applied as an analytical framework for understanding the types of assets that can create value to different 
rural businesses. We use these eight subsets of "rural capital" on the premise that some of these may pre-exist in the rural areas while others may be created or enhanced by business activities, thereby enriching the entrepreneurial environment further.

Table 1: Summarising forms of rural capital

\begin{tabular}{|c|c|c|c|c|}
\hline $\begin{array}{l}\text { Castle (1998) } \\
\text { “Rural capital } \\
\text { comprises..." }\end{array}$ & $\begin{array}{l}\text { Bristol Accord } \\
\text { (OPDM, 2005) } \\
\text { "A sustainable } \\
\text { community } \\
\text { should be..." }\end{array}$ & $\begin{array}{l}\text { Svendsen and } \\
\text { Sorensen } \\
\text { (2007) } \\
\text { "7 empirical } \\
\text { factors for } \\
\text { measuring } \\
\text { capital stocks } \\
\text { and utilization } \\
\text { of capital } \\
\text { stocks..." }\end{array}$ & $\begin{array}{l}\text { Flora and Flora } \\
\text { (2008) } \\
\text { "A vital } \\
\text { economy, social } \\
\text { inclusion and a } \\
\text { healthy } \\
\text { ecosystem } \\
\text { requires the } \\
\text { following } \\
\text { capitals..." }\end{array}$ & $\begin{array}{l}\text { Analytical } \\
\text { framework } \\
\text { Translated into: } \\
\text { "capital assets } \\
\text { available to rural } \\
\text { businesses are..." }\end{array}$ \\
\hline Man-created & $\begin{array}{l}\text { "well designed } \\
\text { and built" } \\
\text { "Well connected" }\end{array}$ & Physical & Built & $\begin{array}{l}\text { Physical capital } \\
\text { "Infrastructure" }\end{array}$ \\
\hline \multirow[t]{2}{*}{ Natural } & $\begin{array}{l}\text { "environmentally } \\
\text { sensitive" }\end{array}$ & Natural & Natural & $\begin{array}{l}\text { Natural capital } \\
\text { "Environment and } \\
\text { landscape" }\end{array}$ \\
\hline & $\begin{array}{l}\text { "Thriving" } \\
\text { "Well served" }\end{array}$ & Economic & Financial & $\begin{array}{l}\text { Financial capital } \\
\text { "market size, income, } \\
\text { investment" }\end{array}$ \\
\hline Human & & Human & Human & $\begin{array}{l}\text { Human capital } \\
\text { "people and skills" } \\
\text { "entrepreneurial } \\
\text { capabilities" }\end{array}$ \\
\hline \multirow[t]{3}{*}{$\begin{array}{l}\text { Social (expressly } \\
\text { including cultural) }\end{array}$} & & Social & Social & $\begin{array}{l}\text { Social Capital } \\
\text { "Networks, trust and } \\
\text { reciprocity" }\end{array}$ \\
\hline & $\begin{array}{l}\text { "well run" } \\
\text { "Fair for } \\
\text { everyone" }\end{array}$ & Organisational & Political & $\begin{array}{l}\text { Organisational } \\
\text { Capital "governance, } \\
\text { power \& } \\
\text { representation" }\end{array}$ \\
\hline & $\begin{array}{l}\text { "Active inclusive } \\
\text { and safe" }\end{array}$ & Cultural & Cultural & $\begin{array}{l}\text { Cultural capital } \\
\text { "heritage, rituals, } \\
\text { events, stories and } \\
\text { traditions" }\end{array}$ \\
\hline $\begin{array}{l}\text { Rural Capital } \\
\text { (something over } \\
\text { and above the } \\
\text { sum of the parts } \\
\text { above) }\end{array}$ & & & & $\begin{array}{l}\text { Symbolic Capital } \\
\text { "rural identity that } \\
\text { can be conferred to } \\
\text { the business" }\end{array}$ \\
\hline
\end{tabular}


Table 1 helps us to analyse how the interplay of a range of rural capitals can convey particular advantages to rural businesses. The accrual, management, preservation and use of different forms of capital will vary depending upon the nature of the entrepreneur and the interaction of the business with its local context (McKeever et al. 2015). Moyes et al. (2015), in relation to social capital, note that the value of capital can also change over time.

Although their argument that social capital is a "fluid process" (Moyes et al., 2015, p.11) contradicts definitions that it is actually an asset, not a process, this is an important observation. Adapting from Moyes et al. (2015) the development, accrual and use of forms of rural capital can expand, develop, pause, remain static and decline over time. In the case of social capital in particular, its accrual depends on co-operative behaviours which can in turn promote further capital accumulation (Lee et al., 2005; Westlund and Bolton, 2003; Forrest and Kearns, 2001; Putnam, 2000).

The value of social capital for enterprise creation and growth is well documented. (Moyes et al., 2015, Atterton, 2007; Totterman and Sten, 2005; Westlund and Bolton, 2003). However, Dubois (2016) has noted that social capital is often mobilised in a different way in rural areas with pre-existing social connections generating business connections - the reverse of urban networking where business connections are more likely to precede. The recognition that some forms of capital can attract different meanings and can be formed and utilised through different processes in rural areas compared to urban areas demands further reflection.

\section{Rural capitals and diverse rural representations}

Diverse representations of 'the rural' lead to cultural and symbolic capital being appreciated in different ways by different people - both from within and outside of rural space itself. In academic research, there is growing recognition that rural space is often incoherent and contradictory (Halfacree, 2007; Garrod et al., 2017). This can be reflected in the diverse values attributed to forms of capital in rural areas. While a rural cultural identity might be valued for certain traditions, these can be the same traditions that restrict other forms of development and economic capital creation. We could also argue that the natural space itself is both an asset (affordable and productive land, recreational opportunities) and a hindrance (sparse markets, restricted planning, relatively limited infrastructure). This link between representations and practices is widely acknowledged in rural studies (Cloke et al., 2006; Halfacree, 2010), but the implications for rural businesses have received less detailed analysis. For example, representations associated with the rural idyll - namely the peaceful, unchanging, small-scale, fundamentally communitarian landscapes, within which people experience a less hurried lifestyle (Halfacree, 2010) - can influence consumption patterns 
with respect to lifestyle and leisure choices and thus raise question about the best business models for translating this into local economic value. However, a quiet peaceful image may not sit so comfortably alongside polices promoting dynamic rural economies (Bosworth and Willett, 2011).

In rural sociological literature, it has been argued that rural space is made up of three dimensions - the "structural patterns" of the locality itself, the representations or discursive meanings attributed to rural places and the everyday lives or "routine enactments" that occur in those places (Halfacree, 2007; Woods, 2011; Heley and Jones, 2012). Applying this interpretation to rural businesses, we can translate "rural locality" into "structural patterns of the business location and the location of the target market"; "representations of the rural" into "business identity"; and "lives of the rural" into "everyday business practices - the people, business models and extended networks that constitute the business activity". This could offer tools for rural business owners to consider how aspects of rural capital relate to their activities, and thus how they can benefit from and contribute to those capital stocks.

Considering this model of rural space further, we could perhaps argue that to be defined as "rural", a business should operate in a rural locality, have a rural identity and help to fulfil the lives of those living there - not dissimilar to the 3 elements in our earlier Figure 1.

Highlighting the incoherence between some of these features in terms of their value to rural people and to rural consumers reinforces the importance of a deeper understanding of what makes a business 'truly rural'. To be 'truly rural', we argue that these facets of rural spaces and any inconsistencies matter and can shape the direction of a business positively or negatively. To a business that is simply taking advantage of one feature of rural space (e.g. the convenience or low cost of the location) these rural complexities are perhaps more trivial.

Research in Canada has taken this thinking a stage further by suggesting that where businesses promote alternative representations of rural places, they can create "chaotic spaces" where rural localities and lives might subsequently be transformed through new types of activities that reflect those alternative representations (Mitchell and Vanderwerf, 2010). Mitchell and Vanderwerf relate these transformative processes to the notion of Schumpeterian "creative destruction". For businesses to enact changes to places, as in their example of Creemore, there must be local level connections between businesses and rural capitals within the community. Indeed, in Creemore, one might argue that businesses depend on the community for continuing to produce the cultural and physical capitals that add value to their businesses while the community depends on businesses to meet the needs of their "everyday lives". 
In essence, rural businesses are viewed as being important because they serve rural communities (which would be under-served should they disappear), they make an economic contribution based on the resources available in rural areas (e.g. recreation, food and energy production) or they conserve rural environments. In some case they may do more than one of these things. The paperman in Bosworth's earlier work (2012) fitted the first category and the argument proceeded that such businesses are vital for creating social and cultural forms of capital. They provide continuity for rural communities where the market is not large enough to sustain more intense (or any) competition and a sense of coherence with respect to the everyday lives of the rural. By contrast, businesses that employ rural capitals but operate beyond the rural area may use different representations of rurality to market their products or may recognise specific resources and environmental qualities to provide a competitive advantage. Three such cases are presented below, and will help us to consider how the earlier categorisation of rural businesses (Figure 1) might be modified.

\section{Case Studies}

In order to analyse the meaning of the previously vague "sell a rural product" dimension of Bosworth's Venn Diagram and to explore the role of rural capital, three case studies are selected that could fit into areas $A, B$ and $C$ of the diagram, where businesses only fulfil two out of the three rural criteria. The cases are: (i) a retailer whose origins are in a rural area and whose business began serving rural consumers with products designed for other rural business and household applications (ii) a city-based land agent that serves a rural population and applies rural knowledge to deliver their service across a large rural area, and (iii) a scientific products manufacturer for whom the rural setting is important for their precision manufacturing processes.

Analysis of the three cases, Lakeland (formerly Lakeland Plastics), Jas. Martin \& Co. Land Agents and Crystal Scientific explores the scope for a rural capitals framework to enhance our understanding of rural businesses. The cases were selected because of the authors' knowledge of the development of each business allowing a dynamic analysis of the meaning and relevance of rurality for each business. The details presented in the boxes below draw from published materials on their websites supplemented with interviews with representatives from each business that sought information on the background of the business and the significance of the rural location in each case. In particular, the availability and use of rural assets and resources of all kinds were explored within the interviews.

For each case study, the research began by piecing together a historical narrative of the firms and appraisals of their rural identity were interpreted from analysis of their websites. 
Personal contacts were then identified and interviewed with the use of flexible conversation guides in each case based on the earlier groundwork. Lakeland's Marketing Director was interviewed on the telephone, Crystal Scientific's Owner/Managing Director had been interviewed to camera for a DVD about rural enterprises previously commissioned by this paper's co-author, and 3 partners at Jas Martin were interviewed together for approximately 1 hour in their Lincoln office. Subsequently, each interviewee was asked to comment on the accuracy of the vignette generated before the final version was approved.

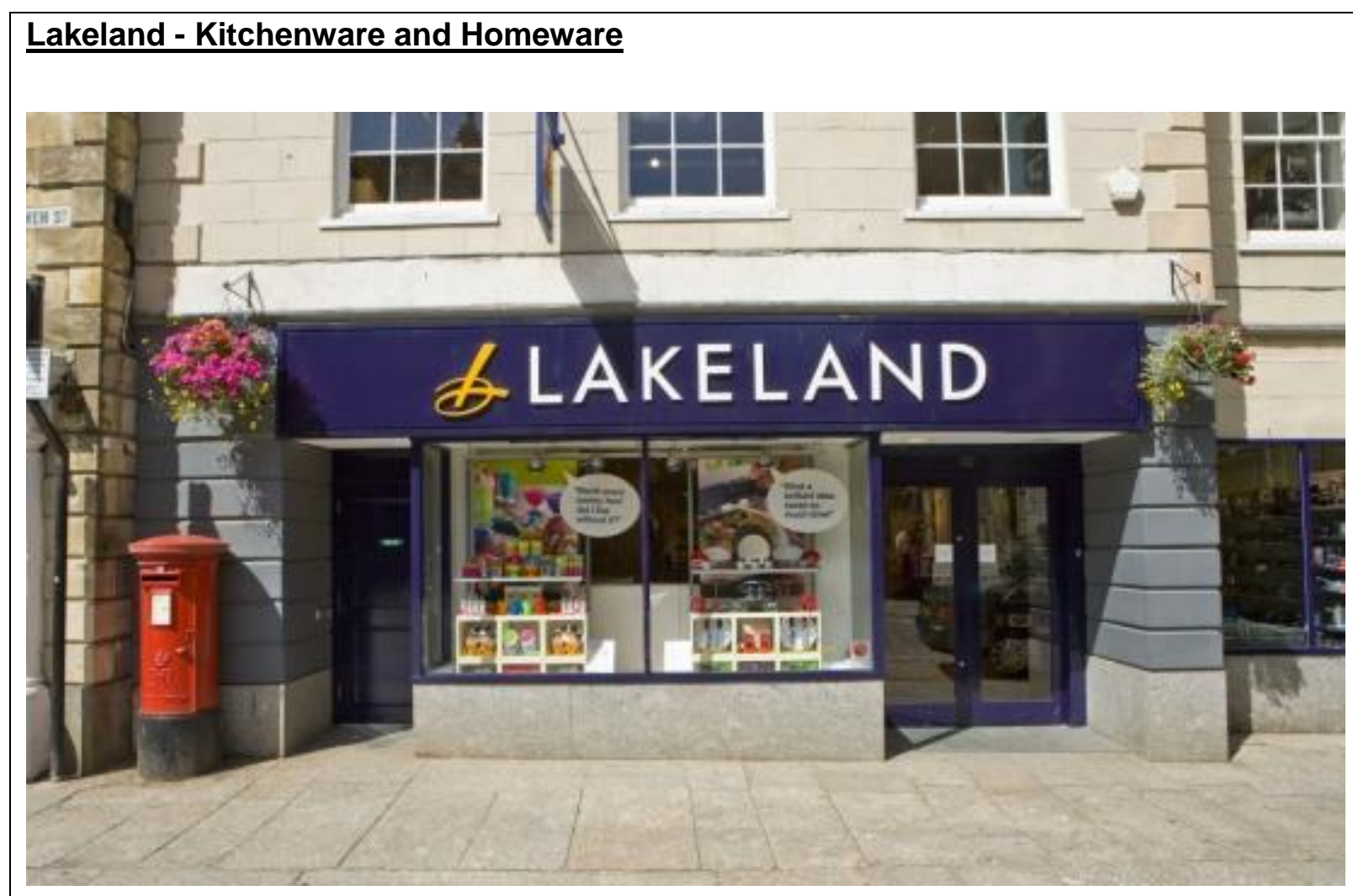

A family firm's journey from agricultural salesman, to national retailer of kitchenware and cookware.

During the 1960s, Alan Rayner an agricultural salesman of animal feed from Windermere, Cumbria, responded to demand from his Lake District farmer customers for plastic sheeting for hay and silage, and plastic bags for freezing home butchered meat produce. Such sales were organised from his garage, supported by his school-age sons, and sold directly and through agricultural shows. As demand, and the range of kitchen utensils and storage products, grew, this activity formed the basis of a new company - Lakeland Plastics.

With increasing encouragement in the late 1960s and 1970s for farm diversification, and with the wider public showing a growing interest in home freezing, Lakeland Plastics became a 
leading supplier of packaging and utensils for this market. As the founder's sons took on the running of the company, they slowly moved the firm away from its farming market, extended their range to kitchenware, products and equipment for cooking, baking and other homeware, became a pioneer in mail order promotion and sales, and opened their first store in Windermere. The family continuity saw the business remain embedded in its rural town location and continuing to employ local people in the rurally-located head office. At the same time, Lakeland Plastics was growing, taking on larger premises close to their founding location and extending their retail market on the way to becoming one of the UK's leading kitchen and homeware suppliers.

Further expansion in the 1990s resulted in, a change of name to Lakeland Limited, opening a large distribution centre at Kendal, spreading their network of stores, many of which were opened in shopping centres and high streets of Britain's major cities and large towns, and adopting the internet as an additional marketing tool. Although still a major player in the local economy, the focus of the business was because less place-dependent, adapting to national and global changes in the retail sector.

In the 2000s further expansion has continued the development of the firm. From its origins as a family micro-business selling a limited range of plastic products to a largely farming market, operating from Windermere, a market town in one of England's most visited National Parks, it has become a large, international retailer. Now simply known as "Lakeland", it has 69 Stores in UK's principal cities and towns from Inverness to Truro, from Canterbury to Enniskillen, a major Distribution centre in Kendal, and stores, partners or agents in the Middle East Gulf Coast states and India. The business uses multi-channel promotion and marketing tools, helped by a workforce approaching 1,500, under the management of family Directors, and selling thousands of product lines in kitchenware, cookware and homeware, to consumers across the United Kingdom and some overseas markets. The Head Office and Flagship store are still located on the site of their early premises in Windermere, in the heart of England's Lake District, and the founding family remain at the helm and heart of the company's management and growth.

The principal source of information used here is http://www.lakeland.co.uk/info/AboutUs 


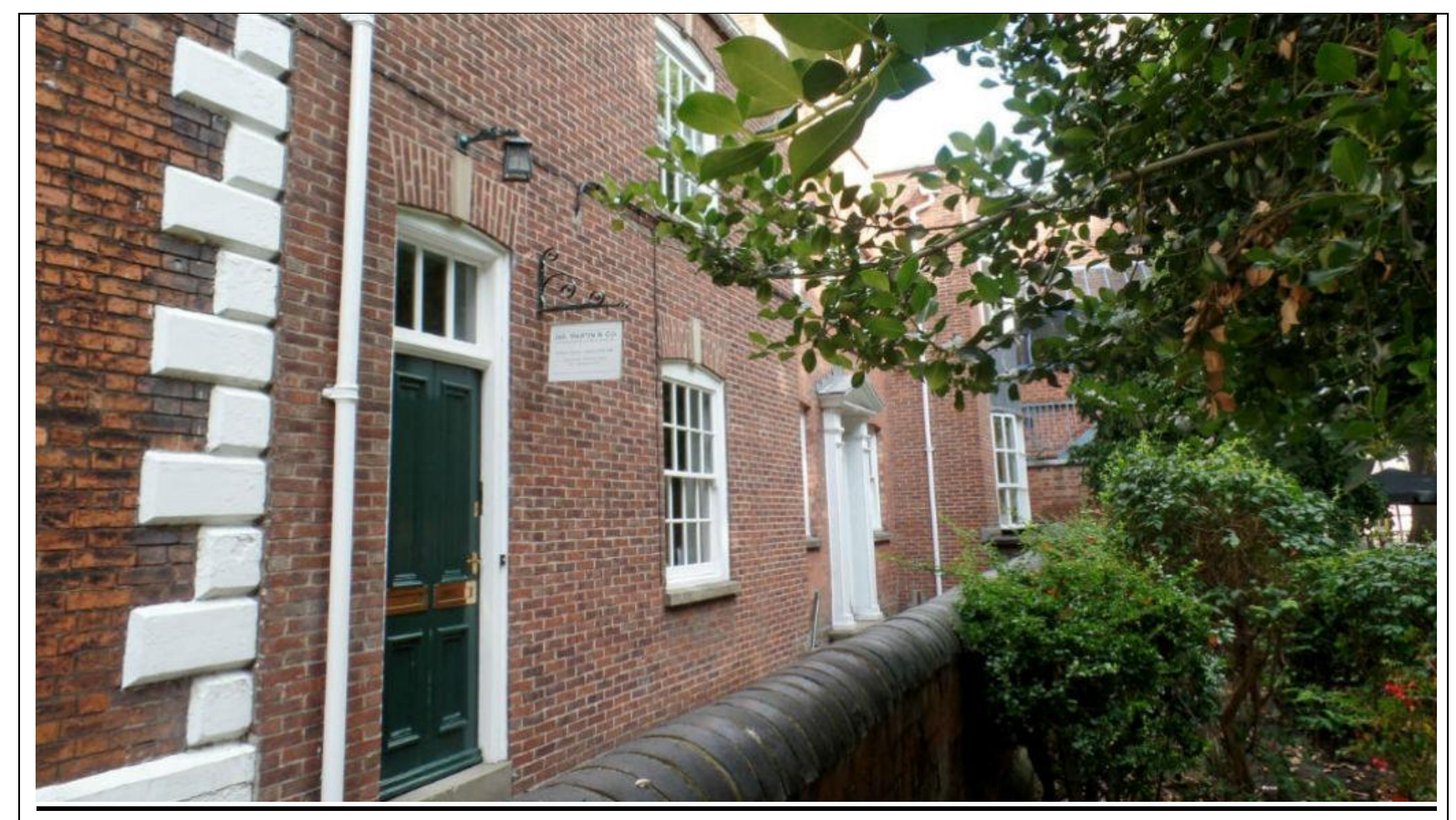

Founded in the mid-19 ${ }^{\text {th }}$ Century in Wainfleet by James Martin, this Lincolnshire firm of land agents has been based in the centre of Lincoln since the first decade of the 1900s. Originally a farmer, James Martin expanded to offer services to other land owners in the area and he was reportedly on a list of the first Council of the Surveyors' Institution formed in 1868.

The firm today has four partners, two other professional surveyors and five office administration and accounts staff. Approximately $75 \%$ of their business is based on providing estate management services to landed families in Lincolnshire and adjoining counties. Services include valuation, sales and letting of agricultural and residential property, planning and development advice, farm business consultancy and a range of financial, accounting and property management services. They only usually take on work further afield if it is linked to an existing client or could generate more local work in the future.

Despite their city centre location, each of the three partners interviewed agreed that they were very much a rural firm. Their identity, building on the long history of the firm, is a key aspect of their USP. Each of the partners interviewed explained that local knowledge, demonstrable rural expertise and trusted relationships were core to their business.

Bigger, national firms would not have the same knowledge of soil types, historical land values, cropping potential and the social fabric of the local area that often plays an important role in the management of an estate. 
Communicating these tacit values in print can be difficult so word of mouth recommendations that can vouch for the expertise of individuals is particularly important. In some cases, this extends to recommendations via other professional associates such as trusted accountants and lawyers who may work together on specific projects but principally it is about being known and having a long term, stable reputation in the County. This is reinforced by their networking activities which focus on major rural events - for example they are long-time sponsors of a conservation award, the Lincolnshire Grey Partridge Trophy, at the County Show.

As a result of the trust placed in the firm's individual advisors, they often provide clients with advice that transcends their core property management role, for example relating to wider legal, financial or environmental issues. They accept that they are generalists, although they were keen to reinforce their expertise in tax and valuation (all are active members of the Central Association of Agricultural Valuers) in addition to their local agricultural and estate management specialisms. Perhaps they could do more to push these particular areas of expertise but this would miss the point... they want to continue to be respected as a firm that will understand their clients, understand the local area and provide a tailored service for whatever the client needs, not just on matters that fit their specialisms.

\section{Crystal Scientific - design and maker of advanced scientific products}

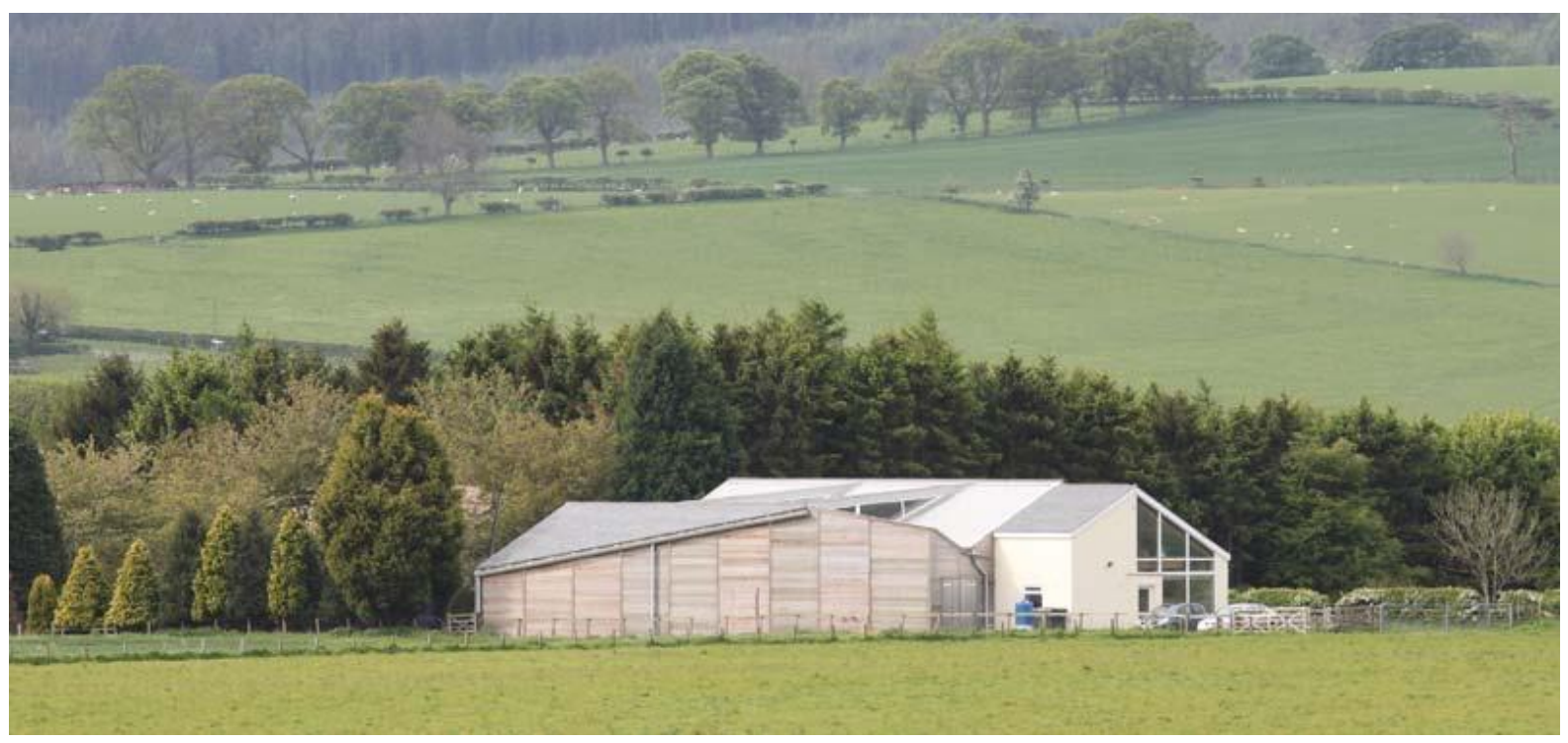

A small unassuming building deep in the countryside of north Northumberland, is the source of highly specialised optics used by the world's scientific and research communities. The micro-business that occupies it, Crystal Scientific, was founded in 1995 by Dr Simon Cockerton, a research physicist trained in leading UK Universities. He moved into commercial 
activity to develop, manufacture and supply diffraction crystals required by Government and Higher Education research facilities on most continents, and in the late 1990s extended its range of products and services to fill a growing niche in the market for the manufacturer and restoration of x-ray mirrors. These products are particularly used in the world's Synchrotons - extremely powerful sources of $x$-rays - which are used in a variety of experimental and commercial uses to better understand and test the structure of matter and material from subnanometer levels to millimetre level important for example in medical imaging. The largest and newest in the UK was opened in 1996 at the Harwell Science Business park in Oxfordshire. [This Diamond Light Synchroton produces brilliant x-rays which can be used in medical, material science, biology and other uses which benefit from imaging created by radiation. There uses can allow physically hidden features to become visible, scientists to understand structure of very, very small quantities or properties or changes that occur too fast to see or measure by other means, including medical imaging]

The firm commenced in a small workshop in Lee Moor Business Park, Near Alnwick, Northumberland - itself a diverse rural business created from former tenanted farm on the Duke of Northumberland's estates. In 2002 it acquired the assets of Colorado-based rival that assisted its development into the market for reflection optics, i.e. scientific and industrial mirrors.

The firm continued to grow and in 2008 moved to a purpose designed building in the countryside near to the National Park. Speaking to the Countryside Agency \& Enterprise Agency (2004) Dr Cockerton explained the benefits of the rural environment of the Lee Moor Business Park as being its secure, crime free and safe environment. With advanced expensive machinery, critical computers and high value products, a secure environment is a reasonable expectation. The company's web site also draws attention to other benefits of their current rural environment, its northern location and its new purpose designed workshop environment, sic:

"Our rural location minimises vibration which is a key requirement for the high precision work that we undertake", whilst the careful design of the workshop "ensure the best conditions for creating high quality mirrors and crystals. The windows all face north to reduce the heating effect of the sun and have been designed in a way to allow natural light to enter most parts of the unit. The walls are super insulated to a thickness of $0.5 \mathrm{~m}$ and the whole factory floor is temperature controlled. Both of these factors minimise temperature fluctuations, which is most important in this technology"

Five people including the founder managing director are employed in this company. As well as the links to his former research and commercial locations, Dr Cockerton clearly appreciates 
the rural and northern locations including its proximity to the university communities of Newcastle and Durham "- each well known for their universities and with strong links to x-ray applications and the synchrotron community".

\section{Employing and creating diverse forms "rural capital"}

Jas Martin fit neatly into section B of the earlier Venn Diagram (Figure 1), being located in an urban area but serving a rural population and delivering a service with a rural identity that relies on rural expertise and local knowledge. The nature of this "rural product" is somewhat intangible, confirming the need to clarify this dimension of the diagram. For Jas Martin, the human, social and symbolic capitals employed in the business each have clear rural characteristics. The human capital, in the forms of specialist agricultural, estate and land management skills combined with local knowledge, is evident in the vignette above. In terms of social capital, the importance of word of mouth recommendations, the need to be trusted and the need to be respected as local experts all demand that the firm's networks are embedded in the rural economy. In line with Dubois' (2016) observation that social networks tend to influence business networks in rural economies (rather than vice versa in urban economies), word of mouth, trust and a rural reputation for Jas Martin are strongly embedded in their social networks demonstrating that a firm based in a city centre can perform as rural professionals and portray themselves as rural through their networks.

More complex for Jas Martin is the nature of symbolic capital. The interviewees lightheartedly pointed to the selection of tweed jackets hanging on the back of the office door as evidence of their rural identity. This was followed by a serious point about how they differentiate themselves from national competitors, many of whom would see 'rural' as a smaller part of their portfolio. Rather than adopting a corporate, urban image, their rural identity and style of working reinforce local knowledge and personal understanding about the "everyday lives" as well as the professional requirements and expectations of their clients. As one of the firm's partners commented, estate owners and farmers want to deal with people "who know their way around a farm". Together, their rural identity and local knowledge combine to give an authentic, trustworthy portrayal for the firm and create a more distinctive offer to their clients for whom they provide more personalised services that often extend well beyond the remit of their competitors. Clearly then, their service draws on forms of rural capital as set out in the literature and this informs the tightening of the top right circle in the revised Venn Diagram in Figure 2. 
Moving to Crystal Scientific, they would be placed in only one of the three criteria in the earlier Venn Diagram (based in a rural location) and thus could not be judged to be a rural business as neither the target customers nor the product could be considered "rural". However, from the vignette above it is clear that the rural location is important for their manufacturing process. If this diagram were revised (Fig. 2), we can place this firm into category $\mathrm{C}$ because value is drawn from the rural "natural capital" which helps to define the production, if not the product, as "rural". Although operating principally in the global scientific community, the rural locality offers added value to the business due to its peaceful character relative to more urbanised developed sites. The connections between the rural location and nearby urban knowledge centres reinforce the viability of this location, which also demonstrates how rural areas are now better able to exploit human and social capital across wider distances, diminishing the disadvantages of remoteness. Just as Moyes et al.'s crematorium succeeded in part due to its peaceful rural location, the same could be said for this scientific manufacturer who made the express choice for a quiet, vibration-free setting.

The other forms of capital that are critical here include the built or physical capital - the building itself being designed to function most effectively within its environment and the technological connectivity that is essential for participating in global science networks. Here the interaction of the entrepreneur and the rural context is more negotiated as the human activity requires interventions to make the rural setting work. Rural entrepreneurs, working within rural settings can create new forms of rural capital - in this case improved connectivity - which might also benefit other people and businesses in the locality.

For human and social capital, however, Crystal Scientific requires external sources of information and regular interactions with external networks. Given that these are global and often virtual, they are less locationally constrained for this business compared to others where a critical mass of like-minded people physically co-located might be more important. The business is able to trade-off the network-remoteness for the unique natural capital of the rural setting. As part of this trade, new rural capital is created through other forms of technological and physical capitals.

Figure 2: Revised Venn Diagram for characterising rural businesses

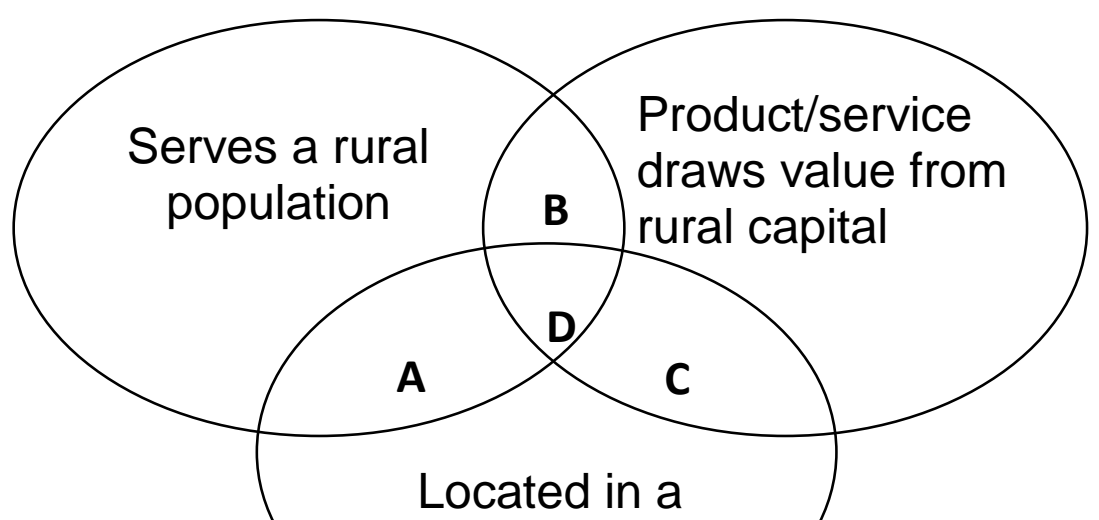


Assessing Lakeland's rural identity is more complex as arguably it can be analysed as three very different businesses, starting out as an agricultural supplier, then moving into wider household markets, before becoming a national/international retailer. At the first stage there would be little doubt that it satisfied at least two criteria - serving a rural population and being located in a rural area. Indeed, it could be argued that the products might be considered rural given that they were principally designed for agricultural uses. At this stage, human capital in the form of rural market knowledge was a core resource and the routes to market were strongly connected to the local agricultural community and the "everyday lives of the rural" (Halfacree, 2007).

Moving forwards the business has maintained a rural location, with its Head Office still in rural Cumbria, but the target population is no longer predominantly rural and the product range has diversified considerably. This reflects Halfacree's observation that the everyday lives of rural people have evolved to encompass new consumer demands. Whilst in the second stage Lakeland continued to address the changing demands of a rural (and urban) population, it could thus still be judged to fit into our category A. In its current form, however, Lakeland is clearly targeting a national/international market through retail outlets in urban locations. If this was an established retailer serving households in cities, towns and rural areas across the nation, that relocated its head office to a rural location, it is unlikely that they would be considered 'rural' as they would only meet one of the three criteria, i.e. rural location. However, Lakeland's story is different, because arguably the human and territorial capital that has driven growth of the company still forms part of a complex set of inputs that make Lakeland a successful national retailer. From a path dependency perspective, it is therefore impossible to ignore the role that rurality has played.

One might assume that Lakeland's brand today also exploits rural capital with the company name firmly rooted in rural culture and thus conveying a rural identity. However, their Marketing Manager observed "I don't think our customers or suppliers would see the rural label as relevant" and "Lakeland and this place is only a part of our company's brand". For other businesses that sell products with rural provenance, the symbolic or cultural capital 
generated could add considerably to potential profitability and influence routes to markets. Although not the case here, Lakeland is an important business for its local rural economy as the Marketing Manager went on to explain, "We benefit from loyalty of employees and local people", which indicates that the rural heritage and identity of the firm is still recognised as a source of value and thus the business model relies on aspects of its rural location.

The three cases illustrate that the rural character of a business can be seen within its production processes and business models. Accordingly we would suggest that these features should be incorporated into the inadequate epithet 'Rural Product' in Figure 1, to improve this criterion as in Figure 2 where the product or service draws value from rural capital". With reference to the totality of rural capitals presented here, this might apply to the production process, the marketing of a product or the customer relationships that sustain the business. This offers clearer and more holistic insight to the rural character of businesses than the earlier test of "Sell a rural product".

Returning to Korsgaard et al. (2015), each of these cases is very difficult to place within either of their categories of 'rural entrepreneurship' or 'entrepreneurship in the rural'. While Lakeland's origin were strongly embedded in the local economy, the rural location has arguably become more of a site of convenience, perhaps best explained by a path dependent trajectory than one of local embeddedness through either resource dependency or value creation within the rural setting. For Crystal Scientific, there is little doubt that the spatial context of the very local rural environment matters, yet from an economic trading perspective, it shows a low level of embeddedness. This questions the usefulness of Kosgaard et al's distinction in isolation and encourages a deeper conceptualisation of the types of capital that add value to rural businesses at either end of their spectrum between the embedded "rural entrepreneur" and their disconnected "entrepreneur in the rural".

\section{Discussion - rural businesses, rural capital and the vitality of rural places}

Applying a rural capitals framework from community-based literature rather than from the economistic "territorial capital" literature identifies the close connections between rural businesses and their communities. Unlike Perucca (2014) and Camagni and Capello (2009) we are not seeking to promote economic growth as the sole aim but to understand the mechanisms of value creation linked to business activities that enable continuity within rural places. The sparse, diverse and sometimes incoherent (Halfacree, 2007) character of rural places precludes the potential for a defined "system of territorial assets" (Perucca, 2014, 
p.537) but instead rural businesses build understanding about, and relationships with, different components of rural and urban capitals. It is those rural businesses which adapt to changes in their localities that provide a sense of continuity where the present and future are seen as iterations occurring across both social and economic dimensions. Within this process, rural businesses are also instigators of change (Finke and Bosworth, 2016), drawing in new consumers, introducing different products and supporting infrastructure developments.

Such thinking mirrors Mitchell and Vanderwerf's (2010) argument that new landscapes emerge from economic transformations in which the drivers of change are rural businesses exploiting new opportunities. At the level of the individual firm, this leads us to examine how various forms of capital, not only natural/landscape capital, are transformed by rural businesses. The first case sees professional knowledge re-packaged as "rural expertise" and estate landscapes are to some extent shaped by the management practices, ownership and property development advocated by the firm. In the second of our three cases, a scientific manufacturer benefits from natural capital to engage in high value, international supply chains, but with minimal impact upon that local environment. The third example outlines how the growth of a national retailer adopted a variety of rural and economic capitals connected to its rural location, and through its current head office and distribution premises, provides larger scale employment as well as income to the local economy.

While these are only three case studies, they highlight that the capitals available to rural businesses are diverse and can generate values in a variety of ways. This has been shown with social capital, which accumulates through regular interactions, learning and trustbuilding (Westlund and Bolton 2003) and can be extended to human capital and organisational capital where using these capitals promotes their development. In some cases, this logic also applies to capitals associated with the rural locality; e.g. natural and physical capital can be augmented through uses which value landscapes, or demand superior infrastructure. Appreciation of these capitals should promote better management of assets, whilst investment in their amelioration should yield positive returns to local business and local communities.

Returning to the typology, businesses that are not drawing value from local stocks of rural capital would derive little benefit from landscape management, local social networks or cultural capital. Indeed, we can start to think about the ways in which different categories of 'rural business' identified through the Venn Diagram create and benefit from different types 
of capital. For example, a rural service business such as a village shop or pub (category A) creates both social and cultural capital as a meeting place and often a cultural landmark (Markham, 2013). In turn, these businesses can benefit from customer loyalty if they are supported by local social capital and from cultural capital if they can use heritage or a local brand identity to attract customers from outside of the local area. The rural experts that might operate from an urban location but serve rural people (such as the land agent herein but also vets, environmental consultants, rural planners or farm consultants) both use and enhance rural knowledge, boosting human capital skills and, in some cases, improving the management of the natural environment.

For businesses in Category $\mathrm{C}$, including two of the cases reported above, the business model or mode of production relies on values drawn from rural cultural and natural capitals. For Jas Martin, in Category B, the rural character of the service that they offer is also a key differentiator that enhances their competitiveness in their well-defined market. Especially in the recreation or local food sectors, firms are "exporting" rural products and targeting sections of the population drawn to positive representations of rural spaces. As a result, these types of businesses are likely to add value to certain cultural and landscape capitals so that they can continue to earn economic capital from their localities and identities. In all of these scenarios, being "rural" matters in ways that transcend pure location. In Marshallian economics, a rural location is viewed as a disadvantage - it is not urban and therefore it is remote and peripheral with lower efficiencies and higher transactions costs. By contrast, we argue that a rural identity and other forms of rural capital can offer important advantages to businesses but their local distinctiveness and complexities make it difficult to categorise a 'rural business' solely on its location or solely on its identity.

Once the value of different forms of rural capital are better appreciated, businesses are able to trade-off these capitals to compensate for other rural disadvantages. This is already mentioned in the case of Crystal Scientific, where their network-remoteness is the sacrifice for the environmental attributes of the location. For Jas Martin, the rural identity might be a disadvantage outside of that territory where their skills and tacit knowledge may be less well understood, but it gives them a much more competitive position in the areas where they can trade most successfully. Lakeland have moved a little in the other direction, down-playing their rural brand as the company has expanded but arguably the rural roots have afforded the company with that opportunity as its earlier stages of growth were partly founded on different forms of rural capital. Further observation could be made about the rural location itself influencing the future trajectory of business developments. Lakeland and Jas Martin have been to some extent path dependent upon the identity and business reach afforded by 
their locations. To break out of this requires a major rebranding or reinvention of the firm structure. Although a more recent rural establishment, Crystal Scientific may find its future development shaped by the rural location too.

\section{Policy implications}

The foregoing analysis and examination of qualities and values of rural capital has important implications for business owners/managers and for those who provide advice and support to businesses. It may also inform those with responsibility for developing and applying rural and economic policies. This latter community - whether at the EU level or that of an individual local authority's administrative territory - has a tendency to target or bound many policies or programmes, by function (e.g. to improve transport connections or operations) or by specific social or economic drivers (e.g. increase exporting, product innovation or skills training). Alternatively, policies are designed to target certain groups of beneficiaries (e.g. Living wage to reduce in-work poverty) or identifiable territorial areas. City Deals, The Northern Powerhouse and National Parks are UK examples of this latter tendency but few national or sub-national economic policies are solely targeted at rural localities (Category $\mathrm{C}$ in our Venn Diagram). In UK regional policy, a number of measures such as City Deals, The Midland Engine and Enterprise Zones are designed or resourced to emphasise cities and large towns, offering little or no recognition of the nature or needs of rural and small town economies.

When viewed through the lens of "rural entrepreneurs" or "entrepreneurs in rural areas", more business and rural policies and programmes tend to align with one of our three distinct categories in Figure 2, than with the central overlapping category $D$ of sustainable rural enterprises, harnessing and contributing equally to rural location, population and products The LEADER rural development programme is a (rare) example of a policy and programme that has the ability to seek and support this collective agenda. The disadvantage of such policies predominantly aligned to one of the three criteria, is that inclusivity has a habit of leading to exclusivity.

Where rural business, employment and investment are specifically targeted, as in UK governments' strategies for The Rural Economy or Scottish Rural Development Programme, most emphasise firms and activities which produce distinctively rural products. Support or interventions will thus favour, or even be confined to, sectors and firms that produce them. These are usually seen as land-dependant industries (farming, forestry, fishing) food and drink; and rural tourism, with acknowledgement of some forms of renewable energy. In 
these programmes, even allied businesses, providing services to these rural industries, such as electricians, builders, machinery sales and maintenance, may find less public support.

Similarly policies or programmes focused on rural services, tend not to encompass private businesses that support rural populations or again only address a subset. This can be seen in support for rural shops - which target either the sole village shop, or offer rate reliefs only for very small shops. The revised Venn Diagram helps to signify that rural business policy can be directed towards three distinct domains of influence; the rural population and service provision, the efficient use of rural resources and the inequalities or (lack of) connectivity affecting rural places. These policy domains are illustrated in Figure 3.

Figure 3: Aligning the revised Venn Diagram to policy objectives

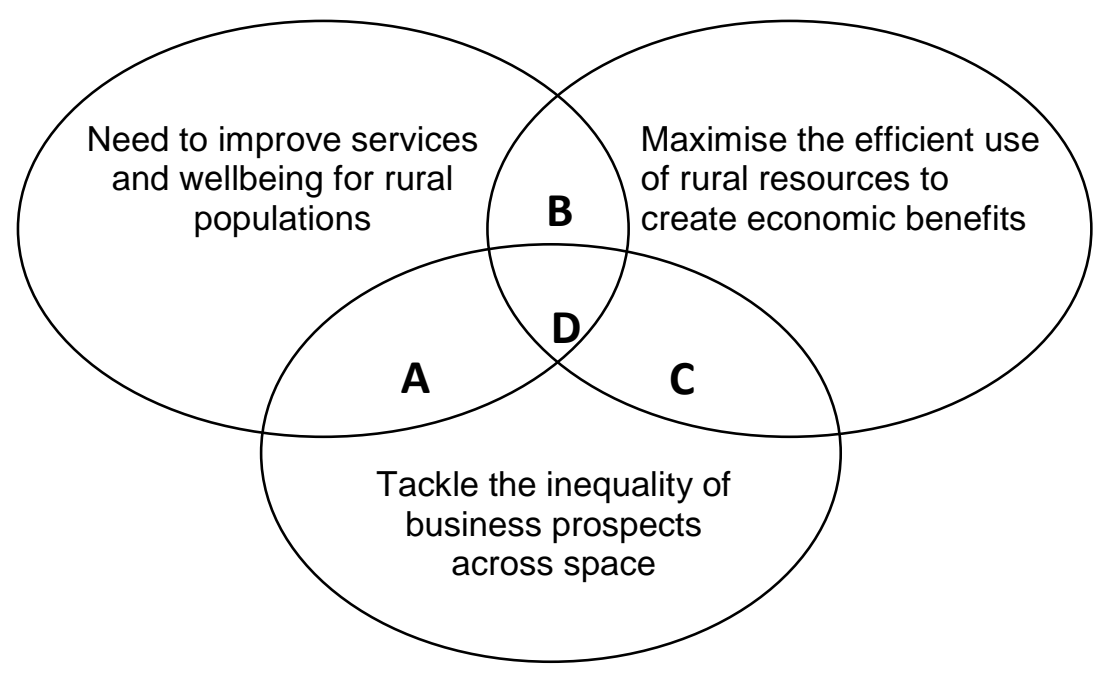

Figure 3 is also helpful as it illustrates that rural businesses in sections $A, B, C$ and $D$ can make significant contribution to these policy objectives. It also demonstrates that joined up thinking in policy can deliver multiple objectives by targeting support towards, and working in partnership with, the rural business community. As an example, a policy initiative to support local supply chains through local public procurement could continue to deliver key local services while simultaneously increasing the efficient use of local resources and compensating firms operating in relatively sparse markets. Applying the framework above to 
any rural development or business policy could help implementation to achieve more clearly defined, and potentially wider goals.

Policy approaches that are more inclusive and recognise the diversity of business activities in rural areas can promote wider rural development. Where businesses are creating and benefiting from rural capitals of all kinds, successful businesses should help to sustain the economic, social, cultural and built environments of rural places. Drawing on findings from Huggins et al. (2015), who observed that entrepreneurial culture and social cohesion can be conducive to enterprise development and new start-ups, virtuous cycles of business growth supporting thriving rural communities should be the goal. However, as with all spirals, the chances for less favoured and peripheral regions are more precarious. Huggins et al also observed that "regional entrepreneurship differentials emerge due to the spatial and placebased nature of three underlying factors: the nature of markets, the nature of innovation systems and the nature of the place-based cultures, communities and the innovations they establish" (2015, p497). Translating this into purely rural factors, this might be termed as "access to markets", "participation in innovation systems" and "cultural capital", each of which should become policy goals for rural businesses.

Once we recognise that rural businesses are increasingly diverse and draw value from their locality through a number of forms of capital, additional factors emerge as challenges for their growth and profitability. These may include hard-to-fill vacancies due to poor transport or unaffordable housing, additional distance and cost of transport to business suppliers and consumers; limited business networking; or compliance with rurally-distinct regulations, all of which have been identified as barriers or obstacles to rural business growth in major business surveys. For example, Lee and Cowling (2015), re-analysed a substantial sample of responses from a large survey of small businesses, to test the question whether rural and non-rural firms perceive different obstacles to business success. Whilst they discovered some differences between spatial samples, especially on the impact of regulations, and on skills shortages, they concluded that "place is not a particularly important determinant of the extent to which firms perceive barriers to growth" $(2015, \mathrm{p} 40)$. This opens up questions about whether business policies should be targeted at rurally-located firms at all, but Lee and Cowling add, "other justifications for such policy may still exist. For example, specific factors related to rural areas... may make it appropriate to have geographically targeted policy" (ibid, p40). Perhaps our analysis, as extended in this paper, offers a basis for identifying such factors that affect entrepreneurs and businesses in rural areas and merit spatially-differentiated economic or business policies and programmes. 


\section{Concluding thoughts}

Rather than seeking to define and categorise all types of rural businesses, new research should consider how entrepreneurs can seek to exploit diverse forms of rural capitals to strengthen their business models. This might open up a new research agenda to tighten the meaning of "rural capital" too. From a broader rural development perspective, if these capitals are more overtly connected to value creation, it indicates that there are also economic reasons for a continuing rural policy agenda. For example, specific questions might be: How does "rural-ness" create value for rural enterprises? What "rural penalty" exists and how can rural entrepreneurs overcome it? How do rural entrepreneurs contribute to their local rural economies and communities? and What amendments to policies, programmes and resources are needed to address these values, penalties and contributions?

By challenging the hegemony of a "rural penalty", and seeking aspects of comparative advantage that lie within the suite of rural capitals available to businesses, we can think about rural businesses as creators of value more broadly, including their contribution to community development. Such an approach should help rural business policy to become less 'relational' in its nature and shift from compensating for 'not being urban', and instead becoming more tailored to promoting the opportunities that pervade within rural contexts.

For businesses themselves, recognising the extent to which they have a rural identity and the extent to which rural capitals offer value-creating potential, can add to their resilience and growth potential. On one hand, as with our Lakeland case example, it can guide growth that recognises rural origins but also embraces national and international opportunities. On the other hand, for businesses moving into a rural area, and those offering support for such inward investment, it can help them to recognise distinctive forms of capital that are available to help them to embrace their new location. Developing business models that combine local and extra-local integration, mirroring some of the neo-endogenous development literature for rural development theory (Ward et al., 2005; Ray, 2006; Bosworth and Atterton, 2012), can aid their resilience and contributions. For example, if rural businesses are marginalised by network power imbalances which favour actors in urban centres, might rural localities offer alternative allies and sources of support? Alternatively, in a time of rural crisis, extra-local connections might be essential to sustain markets of sufficient scale to bridge local economic challenges. Focusing further on resilience, we might move on to examine which parts of the typology are most resilient, and which forms of rural capital within rural business models are most valuable assets for resiliency. 


\section{References}

Atterton, J. (2007) The 'Strength of Weak Ties': Social Networking by Business Owners in the Highlands and Islands of Scotland. Sociologia Ruralis 47(3), pp. 228-245 Atterton,J. (2016) Scotland's rural economies -Looking beyond the land-based sector. Section 2. Rural Scotland in Focus, 2016. SRUC. Edinburgh Bosworth, G. and Atterton, J. (2012) Entrepreneurial In-migration and Neo-endogenous Rural Development. Rural Sociology 77 (2), pp. 254-279

Bosworth, G. (2012) "Characterising rural businesses - tales from the paperman", Rural Studies, 28(4), pp. 499-506

Bosworth, G. and Willett, J. (2011) Embeddedness or Escapism? Rural perceptions and economic development in Cornwall and Northumberland. Sociologia Ruralis 51(2), pp. 195214

Camagni, R. and Capello, R. (2009) "Territorial Capital and Regional Competitiveness:

Theory and Evidence", Studies in Regional Science 39(1), pp. 19-39

Capello, R. Caragliu, A. and Nijkamp, P. (2009) "Territorial Capital and Regional Growth: Increasing Returns in Cognitive Knowledge Use", Timbergen Institute Discussion Papers. Accessed 20 ${ }^{\text {th }}$ March 2016 at: http://papers.tinbergen.nl/09059.pdf Castle, E. (1998) "A conceptual framework for the study of rural places", American Journal of Agricultural Economics 80, pp. 621-631

CLA (2016) "Standing up for Rural Businesses". Accessed $14^{\text {th }}$ January 2018 at: https://www.cla.org.uk/node/7738

Cloke, P., Marsden, T. and Mooney, P. (2006) (eds): Handbook of Rural Studies, London: Sage.

CRC, (2007-11) State of the Countryside. Commission for Rural Communities, Cheltenham. 2007 to 2011

Dana, L-P., Gurau, C. \& Lasch, F. (2014) Entrepreneurship, tourism and regional development: a tale of two villages. Entrepreneurship \& Regional Development 26(3-4) pp. 357-374

Defra. (2014-17) Quarterly Rural Economic Bulletins. Department of Environment, Food and Rural Affairs. London

Di Domenico, M., and Miller G. (2012) 'Farming and tourism enterprise: Experiential authenticity in the diversification of independent small-scale family farming' Tourism Management 33(2), pp. 285-294

Dubois, A. (2016) Transnationalising entrepreneurship in a peripheral region - The translocal embeddedness paradigm. Journal of Rural Studies 46, pp.1-11 
Emery, M. and Flora, C. (2006) "Spiraling-Up: Mapping Community Transformation with Community Capitals Framework." Community Development: Journal of the Community Development Society 37, pp. 19-35

Finke, H. B. and Bosworth, G. (2016) Exploring the character of rural businesses:

Performing change and continuity. Local Economy 31(5), pp. 619-636

Flora, C. B., and Flora, J. L. (2008). Rural Communities, Legacy and Change ( $3^{\text {rd }}$ Edition). Boulder, CO, USA: Westview Press.

Forrest, R. and Kearns, A. (2001) Social Cohesion, Social Capital and the Neighbourhood Urban Studies, 38(12), pp. 2125-2143

Garrod, G., Phillipson, J., Rowe, F., Shortall, S., Shucksmith, M. and Liddon, A. (2017) After Brexit: 10 key questions for rural policy. Centre for Rural Economy, Newcastle University. Halfacree, K. (2010) "Reading Rural Consumption Practices for Difference", Culture Unbound, 2, pp. 241-263

Halfacree, K. (2007) "Trial by space for a 'radical rural': Introducing alternative localities, representations and lives", Journal of Rural Studies 23, pp.125-141

Haartsen, T., and Van Wissen, L. (2012). Causes and Consequences of Regional Population Decline for Primary Schools. Tijdschrift voor Economische en Sociale Geografie, 103(4), pp. 487-496.

Haartsen, T. and Venhorst, V. (2010) Planning For Decline: Anticipating on Population Decline in the Netherlands. Tijdschrift voor Economische en Sociale Geografie. 101(2), pp. 218-227

Heley, J. and Jones, L. (2012) "Relational rurals: Some thoughts on relating things and theory in rural studies", Journal of Rural Studies 28(3) pp. 208-217

Hess, M. (2004) 'Spatial relationships? Towards a re-conceptualization of embeddedness. Progress in Human Geography 28(2), pp.165-186

Huggins, R. Morgan, B. and Williams, N. (2015) "Regional entrepreneurship and the evolution of public policy and governance: Evidence from three regions", Journal of Small Business and Enterprise Development, 22(3), pp.473-511

Korsgaard, S., Muller, S. and Tenvig, H. (2015) "Rural entrepreneurship or entrepreneurship in the rural - between place and space", International Journal of Entrepreneurial Behavior and Research 21(1) pp. 5-26

Lee, J., Arnason, A., Nightingale, A. and Shucksmith, M. (2005) "Networking: Social Capital and Identities in European Rural Development", Sociologia Ruralis 45(4), pp. 269-283 Lee, N and Cowling, M. (2015) "Do rural firms perceive different problems? Geography, sorting and barriers to growth in UK SMEs", Environment and Planning C; Government and Policy, 33(1) pp. 25-42 
Lichter, D. and Brown, D. (2011) "Rural America in an Urban Society: Changing Social and Spatial Boundaries." Annual Review of Sociology. 37, pp. 565-592

Lowe, P., Ray, C., Ward, N., Wood, D. and Woodward, R. (1998) Participation in Rural Development: A Review of European Experience. Centre for Rural Economy, University of Newcastle

Malecki, E. (2003) "Digital development in rural areas: potentials and pitfalls", Journal of Rural Studies, vol. 19, 201-214

Markham, C. (2013) "The rural public house: cultural icon or social hub?" In Bosworth, G and Somerille, P. (eds) Interpreting rurality: multidisciplinary approaches. Routledge, Abingdon Oxon. pp. 267-277.

McElwee, G. \& Bosworth, G. (2010) Exploring the strategic skills of farmers across a typology of farm diversification approaches. Journal of Farm Management 13(12), pp. 819838

McKeever, E., Jack, S. and Anderson, A. (2015) "Embedded entrepreneurship in the creative re-construction of place", Journal of Business Venturing 30, pp. 50-65 Mitchell, C. and Vanderwerf, J. (2010) Creative Destruction and Trial by Space in a Canadian Village. Geographical Review 100(3), pp. 356-374

Moyes, D., Ferri, P., Henderson, F. and Whittam, G. (2015) "The stairway to Heaven? The effective use of social capital in new venture creation for a rural business", Rural Studies 39, pp. $11-21$

Newbery, R. and Bosworth, G. (2010) Home-based business sectors in the rural economy. Society and Business Review 5(2), pp. 183-197

North, D. and Smallbone, D. (2006) "Developing Entrepreneurship and Enterprise in Europe's Peripheral Rural Areas: Some Issues Facing Policy-makers”, European Planning Studies 14(1) pp. 41-60

Office of the Deputy Prime Minister (OPDM) (2005) Bristol Accord: Conclusions of Ministerial Informal on Sustainable Communities in Europe. Accessed $3^{\text {rd }}$ Feb 2017 at:

http://www.eib.org/attachments/jessica bristol accord sustainable communities.pdf

Perucca, G. (2014) The Role of Territorial Capital in Local Economic Growth: Evidence from Italy. European Planning Studies 22(3), pp. 537-562

Phelan, C. and Sharpley, R. (2012) 'Exploring entrepreneurial skills and competencies in farm tourism', Local Economy, 27(2), pp.103-118.

Phillipson, J., Gorton, M., Maioli, S., Newbery, R., Tiwasing, P.and Turner, R., (2017). Rural business aspirations, obstacles and support: an analysis of the Longitudinal Small Business Survey 2015. ERC Research Paper 58, February 2017. Enterprise Research Centre, Warwick Business School 
Putnam, R. D. (2000) Bowling Alone: The Collapse and Revival of American Community. Simon \& Schuster Paperbacks, New York

Ray, C. (2006) "Neo Endogenous Rural Development in the EU”, Ch 19 in P. Cloke, T. Marsden and P. Mooney (eds) Handbook of Rural Studies, Sage, London Ray, C. (2001) Culture Economies. Centre for Rural Economy, Newcastle REUK. (2017) Small Rural Firms in English Regions: Analysis and Key findings from UK Longitudinal Small Business Survey, 2015. September 2017. Rural Enterprise UK, Newcastle University.

Roberts, E. and Townsend, L. (2016) "The contribution of the creative economy to the resilience of rural communities: Exploring cultural and digital capital", Sociologia Ruralis, 56(2), pp. 197-219.

Rural England (2017) The State of Rural Services 2016 Report. Accessed 21 July 2017 at: https://ruralengland.org/the-state-of-rural-services-2016-report/

Salemink, K., Strijker, D. \& Bosworth, G. (2015) "Rural Development in the Digital Age: a systematic literature review on unequal ICT availability, adoption, and use in rural areas" Journal of Rural Studies. 54, pp. 360-371 http://dx.doi.org/10.1016/.j.jrurstud.2015.09.001 Scottish Government (2016) Small Business Survey Scotland 2015. Topic Report: Urban/Rural Businesses. Scottish Government. Office of the Chief Economic Adviser, Edinburgh. http://www.gov.scot/Topics/Economy/ASBS

Seuneke, P. \& Bock, B. (2015) 'Exploring the roles of women in the development of multifunctional entrepreneurship on family farms: an entrepreneurial learning approach', NJAS- Wageningen Journal of Life Sciences, 74-75, pp.41-50

Slee, R.W. (2005) From countrysides of production to countrysides of consumption? Journal of Agricultural Science 143, pp. 255-265

Stathopolou, A., Psaltopoulos, D. and Skuras, D. (2004) "Rural entrepreneurship in Europe: A research framework and agenda", International Journal of Entrepreneurial Behaviour and Research 10(6), pp. 404-425

Stockdale, A. (2004) "Rural Out-Migration: Community Consequences and Individual Migrant Experiences", Sociologia Ruralis 44(2), pp. 167-194

Stockdale, A. and McCleod, M. (2013) "Pre-Retirement Age Migration to Remote Rural Areas", Journal of Rural Studies 32(2) pp. 80-92

Svendsen, G., and Sorensen, J., (2007) "There's more to the picture than meets the eye: Measuring tangible and intangible capital in two marginal communities in rural Denmark", Journal of Rural Studies, 23, pp. 453-471

Terluin, I. (2003) "Differences in economic development in rural regions of advanced countries: an overview and critical analysis of theories", Journal of Rural Studies 19, pp. 327- 
The Countryside Agency \& Enterprise Agency (2004) "5 Enterprise Stories” A DVD produced for The Countryside Agency, DVD CAX 170, Cheltenham, Gloucs.

Totterman, H. and Sten, J. (2005) Start-ups: Business Incubation and Social Capital.

International Small Business Journal 23(5), pp. 487-511

Turner, R. (2014) "Out of the Shadows: Growth from non-farm rural enterprises. Enterprise

Research Centre White Paper", Accessed $7^{\text {th }}$ Sept 2015 at:

http://www.enterpriseresearch.ac.uk/wp-content/uploads/2014/09/Out-of-the-shadowsformatted.pdf

Ward, N., Atterton, J., Kim,T-Y., Lowe, P., Phillipson, J. and Thompson, N. (2005)

Universities, the Knowledge Economy and 'Neo-endogenous Rural Development'. Centre for Rural Economy, Newcastle University

Westlund, H. and Bolton, R. (2003) Local Social Capital and Entrepreneurship. Small

Business Economics 21(2), pp. 77-113

Woods, M. (2011) "Rural". Routledge, Abingdon.

Wortman Jr, M. (1990) Rural Entrepreneurship Research: An integration into the

Entrepreneurship Field. Agribusiness 6(4), pp. 329-344 